\title{
Front-line paclitaxel and irinotecan combination chemotherapy in advanced non-small-cell lung cancer: a phase I-II trial
}

\author{
GP Stathopoulos*,1, J Dimitroulis ${ }^{2}$, D Antoniou ${ }^{3}$, C Katis ${ }^{4}$, D Tsavdaridis ${ }^{5}$, O Armenaki ${ }^{6}$, C Marosis ${ }^{7}$, \\ P Michalopoulou ${ }^{3}$, T Grigoratou ${ }^{3}$ and J Stathopoulos' \\ 'First Oncology Deptartment, Errikos Dunant Hospital, Athens, Greece; ${ }^{2}$ Sotiria Hospital, 6th Clinic, Greece; ${ }^{3}$ Sotiria Hospital, 7th Clinic, Greece; \\ ${ }^{4}$ Thriacion Hospital, Greece; ${ }^{5}$ IKA Hospital, Thessalonica, Greece; ${ }^{6}$ Sotiria Hospital, 3rd Clinic, SOLCA Study Group, Greece; ${ }^{7}$ Sotiria Hospital, 5 th Clinic, \\ SOLCA Study Group, Greece
}

\begin{abstract}
Our purpose was to determine the efficacy of irinotecan plus paclitaxel administered on day I, repeated every 2 weeks, in untreated patients with advanced or metastatic non-small-cell lung cancer (NSCLC). In total, 56 patients with inoperable or metastatic stage III and IV NSCLC with a histologically or cytologically confirmed diagnosis were enrolled. None of the patients had undergone prior chemotherapy or radiation therapy. Treatment involved irinotecan $125 \mathrm{mg} \mathrm{m}^{-2}$ and paclitaxel $135 \mathrm{mg} \mathrm{m}^{-2}$ administered on day I and repeated every 2 weeks for a planned number of nine cycles. With a standard dose of paclitaxel at $135 \mathrm{mg} \mathrm{m}^{-2}$, the dosage of irinotecan was escalated at four levels: 75, 100, 125 and $150 \mathrm{mg} \mathrm{m}^{-2} ; 125 \mathrm{mg} \mathrm{m}^{-2}$ was established as the maximum tolerated dose; this dosage was administered to 46 patients. A total of 52 patients (median age 65 years, range $38-77$ years) were assessable for toxicity and survival and 46 for response rate. Out of 46 evaluable patients, 19 achieved partial response (4I.3\%), 17 had stable disease (37\%) and 10 (21.7\%) experienced disease progression. The median duration of response was 6 months (range 2-9+ months). The main adverse reactions were myelotoxicity (grades 3 and 4 ) in 10 (19.2\%) patients and diarrhoea (grade 3 ) in four (7.7\%) patients. Irinotecan combined with paclitaxel, administered every 2 weeks, appears to be an effective treatment for advancedstage NSCLC.

British Journal of Cancer (2005) 93, I I06- I I I I. doi: I 0.1038/sj.bjc.6602827 www.bjcancer.com
\end{abstract}

Published online 25 October 2005

(C) 2005 Cancer Research UK

Keywords: irinotecan; paclitaxel; non-small-cell lung cancer

Advanced-stage non-small-cell lung cancer (NSCLC) patients are still in need of new chemotherapy agents that will improve response rate and survival. New agents have been effectively established for other malignant tumours but very few have been applied in cases of NSCLC. One class of recent cytotoxic drugs are the camptothecins. Irinotecan (CPT-11) is a semisynthetic derivative of camptothecin, which produces a cytotoxic effect through interaction with and stabilisation of DNA/topoisomerase-I cleavable complexes by the active metabolite SN-38. The collision of the transcription apparatus and the stabilisation of the cleavable complex cause damage and lead to cell death (Douillard et al, 2000; Sargent et al, 2001). Irinotecan has been administered in colorectal cancer, mainly in combination with other agents in advanced disease (Wasserman et al, 1999; Saltz et al, 2000; Goldberg et al, 2004); it is also effective in pancreatic cancer (Rocha-Lima et al, 2002; Stathopoulos et al, 2003). The choice of irinotecan for gastrointestinal cancers is more or less empirical and use within clinical trials for other malignant tumours may show equal

*Correspondence: Dr GP Stathopoulos, Semitelou 2A, II5 28 Athens, Greece; E-mail: dr-gps@ath.forthnet.gr

Received 27 June 2005; revised 21 September 2005; accepted 22 September 2005; published online 25 October 2005 effectiveness. Existing data combining irinotecan with other agents such as cisplatin (Cardenal et al, 2003) show an effectiveness comparable to other established treatments in NSCLC (Negoro et al, 2003). For the present study, the second agent selected for combination treatment with irinotecan was paclitaxel, which has been tested as first-line combined treatment for advanced NSCLC (Chang et al, 1996; Greco and Hainsworth, 1997; Belani et al, 1999; Bonomi et al, 2000; Stathopoulos et al, 2004). In vitro combination studies of topoisomerase inhibitors with taxanes have shown conflicting results. In one preclinical study, the combination of a topoisomerase inhibitor in combination with paclitaxel demonstrated synergistic cytotoxicity (Chou et al, 1994). Another preclinical study has shown that this combination in human NSCLC cell lines is antagonistic (Kaufmann et al, 1996). One interpretation is that these interactions may vary, depending on the cell type studied and the sequence of drug administration (Adjei et al, 2000). It was suggested that this combination be tested in clinical trials.

In the present phase I-II trial, we combined paclitaxel with irinotecan, administering both agents on the same day, repeating treatment every 2 weeks. This biweekly (every 2 weeks) chemotherapy schedule was based on recent trials with proper dosage adjustment and a successful outcome (Cardenal et al, 2003; Negoro et al, 2003). Our objectives were to determine response rate, toxicity, and median and overall survival. 


\section{PATIENTS AND METHODS}

\section{Eligibility criteria}

Eligibility for the study required the following: histologically or cytologically confirmed NSCLC, disease staging (operation for staging was permitted) and defined inoperable stage IIIB, IV, no prior chemotherapy or radiotherapy, bidimensionally measurable disease on physical examination, X-rays, computed tomography (CT), World Health Organisation (WHO) performance status $0-2$, expected survival $\geqslant 12$ weeks, adequate bone marrow reserve (leucocyte count $\geqslant 3500 \mu \mathrm{l}^{-1}$, platelet count $\geqslant 100000 \mu \mathrm{l}^{-1}$ and haemoglobin $\geqslant 10 \mathrm{~g} \mathrm{dl}^{-1}$ ), adequate renal function (serum creatinine $\leqslant 1.5 \mathrm{mg} \mathrm{dl}^{-1}$ ) and liver function (serum bilirubin $\leqslant 1.5 \mathrm{mg} \mathrm{dl}^{-1}$ and serum transaminases $\leqslant$ three times the upper limit of normal (or $\leqslant$ five times the upper limit of normal in cases of liver metastases]), and age $\geqslant 18$ years. In cases with central nervous system (CNS) involvement or any secondary malignancy, patients were excluded. This study was conducted with the approval of our institutional review board and all patients gave their informed consent before entering the study.

\section{Treatment plan}

Paclitaxel and irinotecan were administered in different intensities: once weekly or every 3 weeks with adjusted doses. Paclitaxel was given biweekly (once every 2 weeks) at a dose of $135 \mathrm{mg} \mathrm{m}^{-2}$, in combination with a second agent, and toxicity was well-tolerated (Stathopoulos et al, 2004). The dose of irinotecan combined with another agent, administered on days 1 and 8, repeated every 21 days, varied from 60 to $110 \mathrm{mg} \mathrm{m}^{-2}$ (Kakolyris et al, 2000, 2001; Keresztes et al, 2004). In the present study, our intention was to conduct a phase I study by escalating the dosage of irinotecan while keeping paclitaxel at a standard dose. This was considered necessary since the dose of irinotecan had not been established when given once every 2 weeks in combination with another myelotoxic agent. On the basis of the previously mentioned data, we determined the dosages as follows: four levels of irinotecan starting at $75 \mathrm{mg} \mathrm{m}^{-2}$, increasing the dose by $25 \mathrm{mg} \mathrm{m}^{-2}$ and ending at a dose of $150 \mathrm{mg} \mathrm{m}^{-2}$. We intended to increase the latter to a higher dose if it was well tolerated. The dose of paclitaxel remained at $135 \mathrm{mg} \mathrm{m}^{-2}$, as this had been tested in a biweekly administration in combination with other myelotoxic agents such as carboplatin or navelbine (Stathopoulos et al, 2004). Table 1 shows dose escalation. When the maximum tolerated dose (MTD) was decided upon (detected or reached), it was given to the next recruited patients. Both drugs were infused: first, irinotecan in normal saline $500 \mathrm{~cm}^{3}$ for $90 \mathrm{~min}$ and then paclitaxel in a solution of $300 \mathrm{~mol} \mathrm{mixture} \mathrm{of} 5 \%$ dextrose and normal saline for a $3-\mathrm{h}$ infusion. Premedication of $8 \mathrm{mg}$ dexamethasone and $50 \mathrm{mg}$ diphenhydramine was given $1 \mathrm{~h}$ before paclitaxel administration and repeated every $8 \mathrm{~h}$ for the first day and once daily on days 2 and 3. Ranitidine in a normal saline infusion was given at the beginning of the treatment. Ondansetron (8 mg) was also

Table I Dose escalation scheme

\begin{tabular}{lcccc}
\hline Dose level & $\begin{array}{c}\text { Irinotecan } \\
\mathbf{( m g ~ m}^{-2} \mathbf{)}\end{array}$ & $\begin{array}{c}\text { Paclitaxel } \\
\mathbf{( m g ~ m}^{-2} \mathbf{)}\end{array}$ & $\begin{array}{c}\text { No. of } \\
\text { patients }\end{array}$ & Courses \\
\hline 1 & 75 & 135 & 3 & 12 \\
2 & 100 & 135 & 3 & 12 \\
3 & 125 & 135 & $3+43^{\mathrm{a}}$ & 282 \\
4 & 150 & 135 & 6 & 12 \\
Total & & & & 318 \\
\hline
\end{tabular}

${ }^{\mathrm{a}} \mathrm{A}$ total of 43 patients were in the phase II part of the study, at this dose level. administered at the beginning and at the end of the infusions. The treatment plan was to repeat the drug administration every 2 weeks for nine cycles unless there was disease progression. In cases of myelotoxicity (neutropenia or thrombocytopenia), dose adjustments within a cycle were based on weekly absolute granulocyte and platelet counts and clinical assessment.

\section{Baseline and treatment assessments and evaluation}

Before study entry, all patients underwent the following evaluations: physical examination, tumour evaluation or measurement, WHO performance status, ECG, full blood count, liver and kidney function tests and urinalysis. Staging was determined by chest and abdominal CT scans, bone scan and occasional magnetic resonance imaging. Blood count, blood urea and serum creatinine were measured before each treatment administration and 7 days after treatment. During the treatment period, radiologic tests were conducted after four courses, at the end of the study and after any course if the clinical signs were indicative of disease progression.

Response and toxicity were assessed using standard WHO criteria. Complete response (CR) was considered to be the complete disappearance of any sign of demonstrable disease, partial response $(\mathrm{PR})$ as $\geqslant 50 \%$ reduction of measurable disease and stable disease (SD) as a $<50 \%$ reduction or a $<25 \%$ increase in the sum of the products of the two perpendicular diameters of all measured lesions and the appearance of no new lesions for 8 weeks. Progressive disease (PD) was defined as an increase in the product of the two perpendicular diameters of any measurable lesion by $25 \%$ over the size at the time of maximum regression and the appearance of new areas of malignant disease. The duration of response was measured from the documentation of response (CR or PR) to PD. The time to tumour progression (TTP) was measured from the time of the first dose administration to disease progression. The determination of objective response on computed tomography was performed by two independent radiologists and two experienced oncologists.

\section{Statistical design}

This was an expected two-step phase II study after the integration of the phase I study. According to the trial design, 30 patients were to be enrolled during the first part of the study, and if an objective response rate of $<15 \%$ was achieved, the treatment would have been abandoned; otherwise, 20 additional patients were to be enrolled. The primary end point of the study was the efficacy of the regimen and the secondary end points were overall survival (OS) and tolerance. Overall survival was calculated from the day of enrolment until death. The median probability of survival and median TTP were estimated by the Kaplan-Meier method; confidence intervals (CIs) for response rates were calculated using methods for the exact binomial CI.

\section{RESULTS}

Of the 56 intent-to-treat patients with advanced inoperable NSCLC, enrolled in the study between October 2003 and February 2005, 52 $(92.9 \%)$ were evaluable for toxicity and survival. A total of 46 patients were evaluated for response rate. Three patients at dose escalation level 1 and three at level 2 were excluded as the dosage they received was inferior to the MTD. Four out of 56 patients were nonevaluable: two refused to continue after the first infusion and the other two were excluded due to cardiac disease nonrelated to the toxicity of the treatment. A total of $47(83.9 \%)$ patients were male and nine $(16.1 \%)$ were female (median age 65 years, range $38-77$ years), and 25 and 31 were stage IIIB and IV, respectively. The patients' characteristics at baseline are shown in Table 2. Histology showed 21 squamous cell type, 19 adenocarcinoma, one 
Table 2 Patients' characteristics at baseline

\begin{tabular}{|c|c|c|}
\hline Characteristic & No. of patients & $\%$ \\
\hline No. of patients enrolled & 56 & \\
\hline No. of patients assessable & 52 & 92.9 \\
\hline \multicolumn{3}{|l|}{ Age (years) } \\
\hline \multicolumn{3}{|l|}{ Median, 65} \\
\hline \multicolumn{3}{|l|}{ Range, $38-77$} \\
\hline \multicolumn{3}{|l|}{ Gender } \\
\hline Male & 47 & 83.9 \\
\hline Female & 9 & 16.1 \\
\hline \multicolumn{3}{|l|}{ Performance status (WHO) } \\
\hline 0 & 12 & 21.4 \\
\hline 1 & 33 & 58.9 \\
\hline 2 & 11 & 19.6 \\
\hline \multicolumn{3}{|l|}{ Stage of disease } \\
\hline$\| \mathrm{BB}$ & 25 & 44.6 \\
\hline IV & 31 & 55.4 \\
\hline Total & 56 & 100 \\
\hline \multicolumn{3}{|l|}{ Histologic type } \\
\hline Squamous & 21 & 37.5 \\
\hline Adenocarcinoma & 19 & 33.9 \\
\hline Large cell & I & 1.8 \\
\hline Undifferentiated & 15 & 26.8 \\
\hline Total & 56 & 100 \\
\hline \multicolumn{3}{|l|}{ Tumour differentiation } \\
\hline Well differentiated & 2 & 3.6 \\
\hline Moderately differentiated & 18 & 32.1 \\
\hline Poorly differentiated & 36 & 64.3 \\
\hline \multicolumn{3}{|l|}{ Metastatic site } \\
\hline Bone & 13 & 41.9 \\
\hline Liver & 10 & 32.3 \\
\hline Lung & 4 & 12.9 \\
\hline Adrenal & 2 & 6.5 \\
\hline Brain & 1 & 3.2 \\
\hline Pancreas & 1 & 3.2 \\
\hline Total & 31 & \\
\hline
\end{tabular}

large cell type and 15 undifferentiated or nondefined by cytological examination.

\section{Compliance with treatment-dose intensity}

In total, 318 chemotherapy cycles were administered with a median of 6.63 cycles (range 2-9) per patient. The median interval between cycles was 15 days (range 15-22 days). Expected dose intensity for paclitaxel was $67.5 \mathrm{mg} \mathrm{m}^{-2}$ week $^{-1}$ (mean dose intensity $66.2 \mathrm{mg} \mathrm{m}^{-2}$ week $\left.^{-1}\right)$; the $95 \%$ CI was $65.1-$ $67.2 \mathrm{mg} \mathrm{m}^{-2}$ week $^{-1}$ (median dose intensity $67.5 \mathrm{mg} \mathrm{m}^{-2}$ week $^{-1}$, range $54-67.5 \mathrm{mg} \mathrm{m}^{-2}$ week $^{-1}$ ). The expected dose intensity for irinotecan was $60 \mathrm{mg} \mathrm{m}^{-2}$ week $^{-1}$ (mean dose intensity $59 \mathrm{mg} \mathrm{m}^{-2}$ week $^{-1}$ ); the $95 \%$ CI was $58.3-59.8 \mathrm{mg} \mathrm{m}^{-2}$ week $^{-1}$ (median $60 \mathrm{mg} \mathrm{m}^{-2}$ week $^{-1}$, range $50-60 \mathrm{mg} \mathrm{m}^{-2}$ week $^{-1}$ ). In four patients, four cycles (once per patient) were delayed by 1 week. Three out of six patients at level four presented with grade 4 neutropenia and four out of six had grade 2 or 3 diarrhoea. In patients at dosage levels 1 and 2, grade 1 neutropenia and grade 1 or 2 diarrhoea were observed in two out of six patients. Of the 46 patients included in the phase II study (at dosage level 3), in two the dosage of both cytotoxic agents was reduced by $25 \%$ (after the third cycle in one, and after the fourth in the other). Treatment delay or dose reduction was due to grade 3 or 4 neutropenia in five

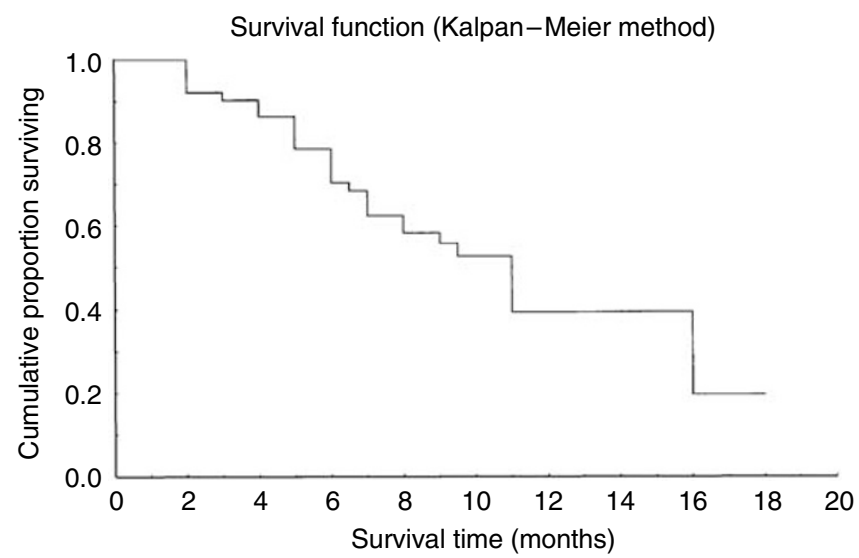

Figure I Survival distribution estimation (Kaplan-Meier method).

cases and to hepatotoxicity (transaminasemia reversible) in one case. At the time of this analysis, 25 patients were still alive (48.1\%) with a median follow-up time of 10 months (range 5-16 months). The Kaplan-Meier method was used for survival distribution estimation (Figure 1).

\section{Response rate and survival}

An objective response rate was observed in 19 out of the 46 evaluable patients $(41.3 \%)$, with a median duration of response of 6 months (range $2-9+$ ). The response rate and duration by stage are shown in Table 3 . The responders were PR and there were no CRs. A total of 17 patients showed SD (37\%) and 10 patients had disease progression (21.7\%). The median TTP was 6 months (range $2-11+$ months).

\section{Toxicity}

In the 15 patients included in the phase I escalation testing, no serious toxicity was observed at levels 1 and 2. Haematologic toxicity was, in general, acceptable at the level 3 dose $\left(125 \mathrm{mg} \mathrm{m}^{-2}\right.$ of irinotecan and $135 \mathrm{mg} \mathrm{m}^{-2}$ of paclitaxel). With regard to the level 4 dosage, $50 \%$ of the patients presented with grade 4 neutropenia and grade 3 diarrhoea. Serious neutropenia was observed in 10 patients (19.2\%): eight with grade $3(15.4 \%)$ and two with grade $4(3.8 \%)$. Febrile neutropenia was seen in three $(5.8 \%)$ of these patients. All of the above patients were treated with haemopoietic growth factor, given on days 6-8 following the previous treatment cycle. Anaemia was common (23 patients), but only four had grade $3(7.7 \%)$. Grades 1 and 2 thrombocytopenia were uncommon (five patients, 9.6\%) (Table 4). Mild nonhaematologic toxicity was observed in the majority of the cases: grade 3 toxicity with diarrhoea in four patients $(7.7 \%)$, alopecia in four patients $(7.7 \%)$, fatigue in one patient $(1.9 \%)$ and allergy in one patient $(1.9 \%)$. Nonhaematologic toxicity is shown in Table 5.

\section{DISCUSSION}

This trial was planned in order to test a new combination as firstline treatment in advanced and inoperable NSCLC. Paclitaxel, one of the two agents, is an established drug in a combined modality for NSCLC patients. Much data exist where paclitaxel has been administered with different agents (mainly cisplatin or carboplatin) (Akerley et al, 1997; Belani et al, 1999; Frasci et al, 1999; Bonomi et al, 2000; Johnson et al, 2004) as first-line treatment in advanced NSCLC. Irinotecan has been administered in NSCLC with agents other than paclitaxel either as second-line (Kakolyris 
Table 3 Response rate and duration ${ }^{\mathrm{a}}$ by stage

\begin{tabular}{lcccc}
\hline Disease stage & PR & SD & PD & Total \\
& $\boldsymbol{n}(\%)$ & $\mathbf{n}(\%)$ & $\boldsymbol{n}(\%)$ & $\boldsymbol{n}(\%)$ \\
\hline IIIB & $11(23.9)$ & $9(19.6)$ & $5(10.9)$ & $25(54.3)$ \\
IV & $8(17.4)$ & $8(17.4)$ & $5(10.9)$ & $21(42.6)$ \\
Total & $19(41.3)$ & $17(37.0)$ & $10(21.7)$ & $46(100)$ \\
\hline
\end{tabular}

aDuration of response: median 6 months (range $2-9+$ months). PR $=$ partial response; $\mathrm{SD}=$ stable disease; $\mathrm{CR}=$ complete response.

Table 4

Haematological toxicity

\begin{tabular}{lcccc}
\hline & $\begin{array}{c}\text { Grade I } \\
\boldsymbol{n ~ ( \% ) ~}\end{array}$ & $\begin{array}{c}\text { Grade 2 } \\
\boldsymbol{n ~ ( \% ) ~}\end{array}$ & $\begin{array}{c}\text { Grade 3 } \\
\boldsymbol{n ~ ( \% ) ~}\end{array}$ & $\begin{array}{c}\text { Grade 4 } \\
\boldsymbol{n ~ ( \% ) ~}\end{array}$ \\
\hline Neutropenia $^{\mathrm{a}}$ & $3(5.8)$ & $13(25)$ & $8(15.4)$ & $2(3.8)$ \\
Anaemia & $17(32.7)$ & $2(3.8)$ & $4(7.7)$ & - \\
Thrombocytopenia & $2(3.8)$ & $3(5.8)$ & - & - \\
\hline
\end{tabular}

${ }^{\mathrm{a}}$ Febrile neutropenia in three patients.

Table 5 Nonhaematologic toxicity

\begin{tabular}{lccc}
\hline & $\begin{array}{c}\text { Grade I } \\
\mathbf{n ~ ( \% )}\end{array}$ & $\begin{array}{c}\text { Grade 2 } \\
\text { n (\%) }\end{array}$ & $\begin{array}{c}\text { Grade 3 } \\
\mathbf{n ~ ( \% )}\end{array}$ \\
\hline Nausea/vomiting & $7(13.5)$ & - & - \\
Diarrhoea & $12(23.1)$ & $4(7.7)$ & $4(7.7)$ \\
Alopecia & $17(32.7)$ & $6(11.5)$ & $4(7.7)$ \\
Fatigue & $8(15.4)$ & - & $1(1.9)$ \\
Allergy & $5(9.6)$ & $1(1.9)$ & $1(1.9)$ \\
Neurotoxicity & $4(7.7)$ & $1(1.9)$ & - \\
Myalgia & $6(11.5)$ & - & - \\
Mucositis & $5(9.6)$ & - & - \\
Cardiotoxicity & $2(3.8)$ & - & - \\
Nephrotoxicity & $1(1.9)$ & - & $(1.9)$ \\
Hepatotoxicity & - & & - \\
\hline
\end{tabular}

et al, 2000, 2001; Keresztes et al, 2004; Ohyanagi et al, 2004) or as front-line treatment with cisplatin (Cardenal et al, 2003; Negoro et al, 2003). It was our hope to further determine the cytotoxic value and effectiveness of irinotecan in NSCLC. In recent years, several new agents have been introduced for the treatment of advanced NSCLC. Some have an established effectiveness, such as taxanes, including docetaxel (Fossella et al, 2000; Georgoulias et al, 2001), gemcitabine (Crino et al, 1997, 1999) and vinorelbine (Le Chevalier et al, 1994; Kouroussis et al, 1998), as well as paclitaxel. Although other new tested agents exist, their effectiveness needs to be confirmed: teniposide, premetrexed and irinotecan are already in use in NSCLC clinical trials. Teniposide in combination with cisplatin produced a reasonably high response rate $(41 \%)$ with a 1-year survival of $43 \%$ (Giaccone et al, 1998). Premetrexed was initially tested as second-line treatment and produced a $23.3 \%$ response rate, with quite high but acceptable toxicity (Rusthoven et al, 1999). Then, premetrexed was combined with cisplatin as first-line treatment and the combination was effective with a $45.8 \%$ response rate, 8.5 months median survival and $40 \%$ 1-year survival (Shepherd et al, 2001). Irinotecan may prove to be a promising agent but further confirmatory trials are required. The existing data are mainly related to second-line treatment using irinotecan on days 1 and 8 and cisplatin on day 8 repeated every 21 days with doses of $100-110$ and $80 \mathrm{mg} \mathrm{m}^{-2}$, respectively: PR was $16.7 \%$ and the main toxicity was grade 3-4 neutropenia (18\%) and diarrhoea (29\%) (Kakolyris et al, 2000). Another trial with the same agents and dosages produced similar toxicity and a $20 \%$ response rate, which cannot be ignored as a second-line chemotherapy following a docetaxel-based front-line regimen (Kakolyris et al, 2001). In another randomised study, irinotecan was combined with docetaxel $v s$ irinotecan with gemcitabine, also as second-line treatment with or without celecoxib, in patients with NSCLC. The dose of irinotecan was $60 \mathrm{mg} \mathrm{m}^{-2}$ when combined with docetaxel and $100 \mathrm{mg} \mathrm{m}^{-2}$ when combined with gemcitabine, administered on days 1 and 8 , with both agents repeated every 21 days. The response rate was low with a PR of $4-8.5 \%$; toxicity was mainly diarrhoea in $13-28 \%$ of the patients, neutropenia in $20-26 \%$ and thrombocytopenia in up to $34 \%$ (the latter was observed only in the irinotecan-gemcitabine combination) (Keresztes et al, 2004). The combination of irinotecan with gemcitabine was the object of another trial as second-line treatment for refractory or relapsed NSCLC. In this latter study, there was a difference, in comparison to the other aforementioned studies, with respect to the dosage of irinotecan and to treatment intensity: irinotecan $150 \mathrm{mg} \mathrm{m}^{-2}$ and gemcitabine $1000 \mathrm{mg} \mathrm{m}^{-2}$ were given on days 1 and 15 , repeated on day 28 . Haematologic toxicity and diarrhoea were lower at $7.4-14.8$ and $3.7 \%$, respectively. The lower toxicity might have been due to eliminating treatment on the 8th day. Response was $18.5 \%$ (Ohyanagi et al, 2004). All of the above trials were preliminary with a small number of patients. In our study, where the drug administration was also every 2 weeks, the $150 \mathrm{mg} \mathrm{m}^{-2}$ dose during phase I, dosage level 4 (six patients), toxicity related to grade 4 neutropenia was detected in three out of six (50\%) patients and grade 3 diarrhoea in three out of six $(50 \%)$ patients. The difference from the previous trial might be due to the combined second agent, which in our study was paclitaxel.

Two other trials have tested irinotecan as first-line chemotherapy. One study combined irinotecan with cisplatin and both agents were given on day 1 and repeated every 3 weeks. The dosage of irinotecan was $200 \mathrm{mg} \mathrm{m}^{-2}$ and cisplatin $80 \mathrm{mg} \mathrm{m}^{-2}$. These investigators achieved a $34.2 \% \mathrm{PR}$ rate and the toxicity, again, was mainly diarrhoea (29\%) and febrile neutropenia (14\%); the 1-year survival was $31 \%$, and the median survival was 8.2 months (Cardenal et al, 2003). The other trial with the irinotecan and cisplatin combination as first-line treatment was a randomised phase III study, comparing this regimen with the cisplatin and vindesine combination, and there was also a third arm with irinotecan alone. The authors concluded that there was no statistically significant difference among the three arms with respect to response rate and survival. In the irinotecan-cisplatin arm, the response rate was higher (50\%) than that of the other arms, but the toxicity was also the highest (diarrhoea $12-15 \%$ ). Irinotecan administration was on days 1,8 and 15, every 4 weeks at a dose of $60 \mathrm{mg} \mathrm{m}^{-2}$ (Negoro et al, 2003).

In a phase I trial, CPT-11 (irinotecan) was one of the three agents used in combination with carboplatin and paclitaxel in NSCLC patients with advanced disease. The treatment was administered once every 3 weeks. Toxicity was high with $50 \%$ myelotoxicity and $19 \%$ febrile neutropenia. These authors suggest the MTD as CPT-11 $100 \mathrm{mg} \mathrm{m}^{-2}$, carboplatin 5 AUC and paclitaxel $175 \mathrm{mg} \mathrm{m}^{-2}$. The response rate of $39 \%$ is not higher than that of other treatments with two agents, but it is quite toxic. The median survival of 11 months was satisfactory, but it is inconclusive as to whether or not the addition of CPT-11 to a well-tested two-drug combination (carboplatin-paclitaxel) affected the efficacy; it is, however, more or less certain that it increased the toxicity (Socinski et al, 2001).

The same combination of CPT-11 $100 \mathrm{mg} \mathrm{m}^{-2}$, carboplatin 5 AUC and paclitaxel $175 \mathrm{mg} \mathrm{m}^{-2}$ once every 3 weeks was given in a phase II study by the same group of investigators who consider that this regimen can be safely administered in NSCLC patients. There was, however, 78\% neutropenia. Responsiveness was $32 \%$ and SD 55\%. The median survival was quite remarkable at 12.5 months (Socinski et al, 2002). 
Another phase I study in NSCLC patients, by a Japanese group of researchers, combined paclitaxel (day 1) with CPT-11 (days 1, 8 and 15) in a 4-week cycle; a dosage of paclitaxel $210 \mathrm{mg} \mathrm{m}^{-2}$ and CPT-11 $50 \mathrm{mg} \mathrm{m}^{-2}$ was defined as dose-limiting toxicity (DLT). The MTD was $50 \mathrm{mg} \mathrm{m}^{-2}$ for CPT-11 and $180 \mathrm{mg} \mathrm{m}^{-2}$ for paclitaxel. The repetition of CPT-11 on days 8 and 15 may not have added to the efficacy but only increased the toxicity (Kasai et al, 2002).

Similar results are given in another phase I-II study where paclitaxel and CPT-11 were combined in NSCLC patients. The treatment was performed every 2 weeks, as in our study, and the recommended dose was $160 \mathrm{mg} \mathrm{m}^{-2}$ for paclitaxel and $60 \mathrm{mg} \mathrm{m}^{-2}$ for CPT-11 - a higher dose of paclitaxel and a much lower dose of CPT-11 as compared to ours. Although the number of patients was only 24 , it is interesting to note that the response rate was $58.3 \%$ and the 1 -year survival was $54.2 \%$ (Yamada et al, 2004).

A phase I study with the paclitaxel and irinotecan combination was different from ours and the aforementioned trials, in that the agents were administered on days 1 and 8 and repeated every 3 weeks. These authors concentrated on the pharmacokinetic analysis and suggested that the MTD was $40 \mathrm{mg} \mathrm{m}^{-2}$ for irinotecan and $50 \mathrm{mg} \mathrm{m}^{-2}$ for paclitaxel. Only nine patients were tested and the effectiveness described was SD (Hotta et al, 2004).

\section{REFERENCES}

Adjei AA, Klein CE, Kastrissios H, Goldberg RM, Alberts SR, Pitot HC, Sloan JA, Reid JM, Hanson LJ, Atherton P, Rubin J, Erlichman C (2000) Phase I and pharmacokinetic study of irinotecan and docetaxel in patients with advanced solid tumors: preliminary evidence of clinical activity. J Clin Oncol 18: 1116-1123

Akerley W, Choy H, Safran H, Sikov W, Rege V, Sambandam S, Wittels E (1997) Weekly paclitaxel in patients with advanced lung cancer: preliminary data from a phase II trial. Semin Oncol 24(Suppl 12): S12-S13

Belani CP, Keams CM, Zuhowski EG, Erkmen K, Hiponia D, Zacharski D, Engstrom C, Ramanathan RK, Capozzoli MJ, Aisner J, Egorin M) (1999) Phase I trial including pharmacokinetic and pharmacodynamic correlations of combination paclitaxel and carboplatin in patients with metastatic non-small-cell lung cancer. J Clin Oncol 17: $676-684$

Bonomi P, Kim KM, Fairclough D, Cella D, Kugler J, Rowinsky E, Jiroutek M, Johnson D (2000) Comparison of survival and quality of life in advanced non-small-cell lung cancer patients with dose levels of paclitaxel combined with cisplatin versus etoposide with cisplatin: results of an Eastern Cooperative Oncology Group trial. J Clin Oncol 18: $623-631$

Cardenal F, Domine M, Massuti B, Carrato A, Felip E, Carrido P, Juan D, Artal A, Barneto I, Lopez-Vivenco G, Balcells M, Rosell R (2003) Three week schedule of irinotecan and cisplatin in advanced non-small cell lung cancer: a multicenter phase II study. Lung Cancer 39: 201-207

Chang AY, de Vore R, Johnson D (1996) Pilot study of vinorelbine (navelbine) and paclitaxel in patients with refractory non-small cell lung cancer. Semin Oncol 23: S19-S21

Chou T-C, Motzer RJ, Tong Y, Bosl GJ (1994) Computerized quantiation of synergism and antagonism of taxol, topotecan, and cisplatin against human teratocarcinoma cell growth: a rational approach to clinical protocol design. J Natl Cancer Inst 86: 1517-1524

Crino L, Scagliotti G, Marangolo M, Figoli F, Clerici M, De Marinis F, Salvati F, Cruciani G, Dogliotti L, Pucci F, Paccagnella A, Adamo V, Altavilla G, Incoronato P, Trippetti M, Mosconi AM, Santucci A, Sorbolini S, Oliva C, Tonato M (1997) Cisplatin-gemcitabine combination in advanced non-small-cell lung cancer: a phase II study. J Clin Oncol 15: 297-303

Crino L, Scagliotti GV, Ricci S, De Marinis F, Rinaldi M, Gridelli C, Ceribelli A, Bianco R, Marangolo M, Di Costanzo F, Sassi M, Barni S, Ravaioli A, Adamo V, Portalone L, Cruciani G, Masotti A, Ferrava G, Gozzelino F, Tonato M (1999) Gemcitabine and cisplatin versus mitomycin, ifosfamide and cisplatin in advanced non-small-cell lung cancer: a
Based on the above, concerning the use of irinotecan in NSCLC, one can assume that (a) this agent is an effective product for this disease, particularly when combined with another cytotoxic drug, and (b) it is nonconclusive as to whether the treatment schedule should be weekly, biweekly (every 2 weeks) or every 3 weeks. Our study produced a response rate of $41.3 \%$, which is higher than that reported in most of the studies with irinotecan and is comparable to other studies with established chemotherapy schedules. Serious neutropenia and diarrhoea in the present trial were approximately $20 \%$. Comparing the toxicity in irinotecan trials, it appears that it is lower and more acceptable when the schedule is repeated every 2 weeks, as shown in our study and also in the other aforementioned study using a biweekly schedule (Ohyanagi et al, 2004). It appears that in eliminating the 8th-day repetition of drug administration, the response rate is not reduced. Whether the biweekly dose of irinotecan should be $125 \mathrm{mg} \mathrm{m}^{-2}$ as in our trial or $150 \mathrm{mg} \mathrm{m}^{-2}$ as in the other trial (Ohyanagi et al, 2004) is debatable, since toxicity and response in both trials were similar. Our lower dose of irinotecan was decided upon because it was combined with paclitaxel, a more myelotoxic agent than cisplatin, which was the agent used in the other study.

Irinotecan combined with paclitaxel as front-line chemotherapy in advanced or metastatic NSCLC is an effective treatment which, when given every 2 weeks, produces well-tolerated toxicity. randomized phase III study of the Italian Lung Cancer Project. J Clin Oncol 17: $3522-3530$

Douillard J, Cunningham D, Roth A, Navarro M, James RD, Karasek P, Jandik P, Ireson T, Carmichael J, Alaki M, Gruia G, Awad L, Rougier P (2000) Irinotecan combined with fluorouracil compared with fluorouracil alone as first-line treatment for metastatic colorectal cancer: a multicentre randomized trial. Lancet 355: $1041-1047$

Fossella F, De Vore R, Kerr RN, Crawford J, Natale RR, Dunphy F, Kalman L, Miller V, Lee JS, Moore M, Gandara D, Karp D, Vokes E, Kris M, Kim Y, Gamza F, Hammers-haimb L (2000) Randomized phase III trial of docetaxel versus vinorelbine or ifosfamide in patients with advanced non-small-cell lung cancer previously treated with platinum-containing chemotherapy regimens. J Clin Oncol 18: 2354-2362

Frasci G, Panza N, Comella P, Nicolella GP, Natale M, Manzione L, Bilancia D, Cioffi R, Maiorino L, De Cataldis G, Belli M, Micillo E, Mascia V, Massidda B, Loruso V, De Lena M, Carpagnano F, Contu A, Pusceddu G Comella G (1999) Cisplatin, gemcitabine and paclitaxel in locally advanced or metastatic non-small-cell lung cancer: a phase I-II study. J Clin Oncol 17: 2316-2325

Georgoulias V, Papadakis E, Alexopoulos A, Tsiafaki X, Rapti A, Veslemes M, Palamidas Ph, Vlachonikolis I (2001) Platinum-based and nonplatinum-based chemotherapy in advanced non-small-cell lung cancer: a randomized multicentre trial. Lancet 357: 1478-1484

Giaccone G, Splinter TAW, Debruyne Ch, Knot GS, Lianes P, van Zandwijk N, Pennucci MC, Scagliotti G, van Meerbeeck J, van Hoesel Q, Curran D, Sahmoud T, Postmus PE (1998) Randomized study of paclitaxelcisplatin versus cisplatin-teniposide in patients with advanced nonsmall-cell lung cancer. J Clin Oncol 16: 2133-2141

Goldberg RM, Sargent DJ, Morton RF, Fuchs CS, Ramanathan RK, Williamson SK, Findlay BP, Pilot HC, Alberts SR (2004) A randomized controlled trial of fluorouracil plus leucovorin, irinotecan, and oxaliplatin combinations in patients with previously untreated metastatic colorectal cancer. J Clin Oncol 22: 23-30

Greco A, Hainsworth JD (1997) Paclitaxel (1-h infusion) plus carboplatin in the treatment of advanced non-small cell lung cancer: results of a multicenter phase II trial. Semin Oncol 24: S12-S14

Hotta K, Usoka H, Kiura K, Tabata M, Kuyama S, Satoli K, Kozuki T, Hisamoto A, Hosokawa S, Fujiwara K, Tanimoto M (2004) A phase I study and pharmacokinetics of irinotecan (CPT-11) and paclitaxel in patients with advanced non-small-cell lung cancer. Lung Cancer 45: $77-84$

Johnson DH, Fehrenbacher L, Novotny WF, Herbst RS, Nemunaitis JJ, Jablons DM, Langer CJ, DE Vore III RF, Gaudreault J, Damico LA, 
Holmgren E, Kabbinavar F (2004) Randomized phase II trial comparing beracizumab plus carboplatin and paclitaxel with carboplatin and paclitaxel alone in previously untreated locally advanced or metastatic non-small-cell lung cancer. J Clin Oncol 22: 2184-2191

Kakolyris S, Kouroussis Ch, Souglakos J, Agelaki S, Kalpakis K, Vardakis N, Vamvakas L, Georgoulias V (2001) Cisplatin and irinotecan (CPT-11) as a second-line treatment in patients with advanced non-small-cell lung cancer. Lung Cancer 34: s71-s76

Kakolyris S, Souglakos J, Agelaki S, Kourousis Ch, Mavroudis D, Sarra E, Malliotakis P, Georgoulias V (2000) A dose-escalation study of irinotecan (CPT-11) in combination with cisplatin in patients with advanced nonsmall-cell lung cancer previously treated with a docetaxel-based front line chemotherapy. Lung Cancer 30: 193-198

Kasai T, Oka M, Soda H, Tsuvutani J, Fukuda M, Nakamura Y, Kawabata S, Nakatomi K, Nagashima S, Takatani H, Fukuda M, Kinoshita A, Kohno S (2002) Phase I and pharmacokinetic study of paclitaxel and irinotecan for patients with advanced non-small-cell lung cancer. Eur J Cancer 38: $1871-1878$

Kaufmann SH, Peeveboom D, Buckwalter CA, Sringen PA, Grochow LB, Donehower RC, Rowinsky EK (1996) Cytotoxic effects of topotecan combined with various anticancer agents in human cancer cell lines. J Natl Cancer Inst 88: 734-741

Keresztes RS, Socinski M, Bonomi P, Chen A, Hart L, Lilenbaum R (2004) Phase II randomized trial of irinotecan/docetaxel (ID) or irinotecan/ gemcitabine (IG) with or without celecoxib (CBX) in 2nd-line treatment of non-small-cell lung cancer (NSCLC). ASCO Proceedings Vol. 23. New York, N.Y.: Cornell University

Kouroussis Ch, Androulakis N, Kakolyris S, Souglakos J, Maltezakis G, Metaxaris G, Chalkiadakis G, Samonis G, Vlachonikolis J, Georgoulias V (1998) First line treatment of advanced non-small-cell lung carcinoma with docetaxel and vinorelbine. Cancer 83: 2083-2090

Le Chevalier T, Brisgand D, Douillard JY, Pujol JL, Alberola V, Monnier A, Riviere A, Lianes P, Chomy P, Cigolari S, Gottfried M, Ruffie P, Panizo A, Gaspard MH, Ravaioli A, Besenval M, Besson F, Martinez A, Berthaud P, Tursz T (1994) Randomized study of vinorelbine and cisplatin versus vindesine and cisplatin versus vinorelbine alone in advanced non-smallcell lung cancer: results of a European multicenter trial including 612 patients. J Clin Oncol 12: $360-367$

Negoro S, Masuda N, Takada Y, Sugiura T, Kudoh S, Katakami N, Ariyoshi Y, Ohashi Y, Niitani H, Fukuoka M (2003) Randomized Phase III Trial of irinotecan combined with cisplatin for advanced non-small cell lung cancer. Br J Cancer 10(88/3): 335-341

Ohyanagi F, Nishio M, Horai T, Kasahara K, Shibata K, Takeda Y (2004) A phase II trial of gemcitabine and irinotecan in patients with refractory or relapsednon-small-cell lung cancer. ASCO Proceedings Vol. 23. Tokyo, Japan: Cancer Institute Hospital

Rocha-Lima C-MS, Savarese D, Bruckner H, Dudek A, Eckardt J, Hainsworth J, Yunus F, Lester E, Miller W, Sarille W, Elfring GL, Locker PK, Compton LD, Miller LL, Green MR (2002) Irinotecan plus gemcitabine induces both radiographic and CA-19-9 tumor marker responses in patients with previously untreated advanced pancreatic cancer. J Clin Oncol 20: 1182-1191

Rusthoven JJ, Eisenhauer E, Butts C, Gregg R, Dancey J, Fisher B, Iglesias J (1999) Multitargeted antifolate LY 231514 as first-line chemotherapy for patients with advanced non-small-cell lung cancer. A phase II study National Cancer Institute of Canada Clinical Trials Group. J Clin Oncol 17: $1194-1199$

Saltz LB, Cox JV, Blanke C, Rosen LS, Fehrenbacher L, Moore MJ, Maroun JA, Ackland SP, Locker PK, Pirotta N, Elfring GL, Miller LL (2000) Irinotecan Study Group: Irinotecan plus fluorouracil and leucovorin for metastatic colorectal cancer. $N$ Engl J Med 343: $905-914$

Sargent DJ, Niedzwiecki D, O'Connell MJ, Schilsky RL, Ledermann JA, Leonard P, Seymour M, Miller LL (2001) Recommendation for caution with irinotecan, fluorouracil and leucovorin for colorectal cancer. $N$ Engl J Med 345: $144-145$

Shepherd FA, Dancey J, Arnold A, Neville A, Rusthoven J, Johnson RD, Fisher B, Eisenhauer E (2001) Phase II study of premetrexed disodium, a multitargeted antifolate and cisplatin first-line therapy in patients with advanced non-small-cell lung carcinoma. Cancer 92: $595-600$

Socinski MA, Sandler AB, Israel VK, Gillenwater HH, Miller LL, Locker PK, Antonellini A, Elfring GL, Natale RB (2002) Phase II trial of irinotecan, paclitaxel and carboplatin in patients with previously untreated stage IIIb/IV non-small-cell lung carcinoma. Cancer 95: 1520-1527

Socinski MA, Sandler AB, Miller LL, Locker PK, Hanover CK, Elfring GL, Israel VK, Pirotta N, Natale RB (2001) Phase I trial of the combination of irinotecan, paclitaxel, and carboplatin in patients with advanced nonsmall-cell lung cancer. J Clin Oncol 19: 1078-1087

Stathopoulos GP, Rigatos SK, Dimopoulos MA, Giannakakis T, Foutzilas G, Kouroussis C, Janninis D, Aravantinos G, Androulakis N, Agelaki S, Stathopoulos JG, Georgoulias V (2003) Treatment of pancreatic cancer with a combination of irinotecan (CPT-11) and gemcitabine: a multicenter phase II study by the Greek Cooperative Group for Pancreatic Cancer. Ann Oncol 14: 388-394

Stathopoulos GP, Veslemes M, Georgatou N, Antoniou D, Giamboudakis P, Katis K, Tsavdaridis D, Rigatos SK, Dimitroulis I, Bastani S, Loukides S, Vergos K, Marossis K, Grigoratou T, Kalatzi E, Charalambatou M, Paspalli A, Michalopoulou P, Stoka M, Gerogianni A (2004) Front-line paclitaxel-vinorelbine versus paclitaxel-carboplatin in patients with advanced non-small-cell lung cancer: a randomized phase III trial. Ann Oncol 15: $1048-1055$

Wasserman E, Cuvier C, Lokiec F, Goldivasser F, Kalla S, Mery-Mignard D, Ouldkaci M, Besmaine A, Dupont-Andre G, Mahjoubi M, Marty M, Misset JL, Cvitkovic E (1999) Combination of oxaliplatin plus irinotecan in patients with gastrointestinal tumors: results of two independent phase I studies with pharmacokinetics. J Clin Oncol 17: 1751 - 1759

Yamada K, Ikehara M, Tanaka G, Nomura I, Oshita F, Noda K (2004) Dose escalation study of paclitaxel in combination with fixed-dose irinotecan in patients with advanced non-small-cell lung cancer (JCOG 9807). Oncology 66(2): $94-100$ 